\title{
Dependence of Trichomonas vaginalis upon polyamine backconversion
}

\author{
Nigel Yarlett, ${ }^{1,2}$ Martha P. Martinez, ${ }^{1}$ Burt Goldberg, ${ }^{1,3}$ \\ Debora L. Kramer ${ }^{4}$ and Carl W. Porter ${ }^{4}$ \\ Author for correspondence: Nigel Yarlett. Tel: +1 212346 1246. Fax: +1 2123461586. \\ e-mail: nyarlett@pace.edu
}

\footnotetext{
1,2 Haskins Laboratories ${ }^{1}$ and Department of Chemistry and Physical Sciences², Pace University, 41 Park Row, New York, NY 10038, USA

3 Department of Biology, St Francis College, 180 Remsen Street, Brooklyn, NY 11201, USA

4 Grace Cancer Drug Center, Roswell Park Cancer Institute, Elm and Carlton Streets, Buffalo, NY 14263, USA
}

Trichomonas vaginalis grown for $16 \mathrm{~h}$ in the presence of $\left[{ }^{14} \mathrm{C}\right]$ spermine formed a high intracellular pool of $\left[{ }^{14} \mathrm{C}\right]$ spermidine and a small but detectable pool of $\left[{ }^{14} \mathrm{C}\right]$ putrescine. When $\left[{ }^{3} \mathrm{H}\right]$ putrescine was added to the growth medium, a large intracellular pool of $\left.{ }^{3} \mathrm{H}\right]$ putrescine was found, but it was not further metabolized, confirming previous studies suggesting the absence of a forwarddirected polyamine synthetic pathway in $T$. vaginalis. Spermidine:spermine $N_{1}$-acetyltransferase (SSAT) and polyamine oxidase enzyme activities were detected which collectively converted spermine to spermidine. Polyamine oxidase was localized in the hydrogenosome-enriched fraction, whereas SSAT was found predominantly in the cytosolic fraction. In the presence of saturating substrate, the trichomonad SSAT had an activity of $0.39 \pm 0.09 \mathrm{nmol}$ $\min ^{-1}$ (mg protein) ${ }^{-1}$ (the mean of five analyses) and an apparent $K_{m}$ for spermine of $1.7 \mu \mathrm{M}$. The enzyme was competitively inhibited by di(ethyl)norspermine with a $K_{\mathrm{i}}$ of $28 \mu \mathrm{M}$. Growth studies indicated that $50 \mu \mathrm{M}$ di(ethyl)norspermine caused a $68 \%$ and $84 \%$ reduction in the intracellular concentrations of spermidine and spermine, respectively. The trichomonad polyamine oxidase required FAD as a cofactor and had an apparent $K_{\mathrm{m}}$ of 6.0 $\mu \mathrm{M}$ for $N^{1}$-acetylspermine. The potential of bis(alkyl) polyamine analogues as antitrichomonad agents is discussed.

Keywords: Polyamines, Trichomonas, polyamine oxidation, acetylated polyamines

\section{INTRODUCTION}

The polyamines spermidine and spermine, and their diamine precursor putrescine, are cationic molecules that are essential for cell proliferation and differentiation (Marton \& Pegg, 1995). The intracellular concentration of these ubiquitous molecules is highly regulated by the polyamine metabolic pathway, which influences the synthesis, degradation, uptake and excretion of these cations (Marton \& Pegg, 1995; Ha et al., 1997). Since they are positively charged at physiological $\mathrm{pH}$, polyamines are thought to act by binding electrostatically to macromolecules such as phospholipids, nucleic acids and proteins, and to stabilize these molecules and/or possibly facilitate their conformational shifts (Feurstein et al., 1990). The synthesis of the higher polyamines by

Abbreviations: DENSpm, di(ethyl)norspermine; ODC, ornithine decarboxylase; SSAT, spermidine:spermine $N^{1}$-acetyltransferase eukaryotic cells involves the transfer of an aminopropyl group from decarboxylated $S$-adenosylmethionine to putrescine or spermidine forming methylthioadenosine and spermidine or spermine respectively.

The urogenital parasite Trichomonas vaginalis differs significantly from other eukaryotes in several aspects of its polyamine metabolism. The parasite produces and excretes large amounts of putrescine via an energygenerating arginine dihydrolase pathway (Linstead \& Cranshaw, 1983; Yarlett et al., 1996). The putrescine excreted is used to drive the uptake of spermine via a putrescine:spermine antiporter that selectively transports $1 \mathrm{~mol}$ spermine into the cell while exporting $2 \mathrm{~mol}$ putrescine, effectively balancing the counterion charge (Yarlett \& Bacchi, 1994). It appears therefore, that $T$. vaginalis relies upon exogenously supplied polyamines to satisfy its needs for these molecules. Trypanosoma cruzi epimastigotes have also been shown to depend upon the uptake of putrescine to satisfy their polyamine requirement (Ariyanayagan \& Fairlamb, 1997), hence 


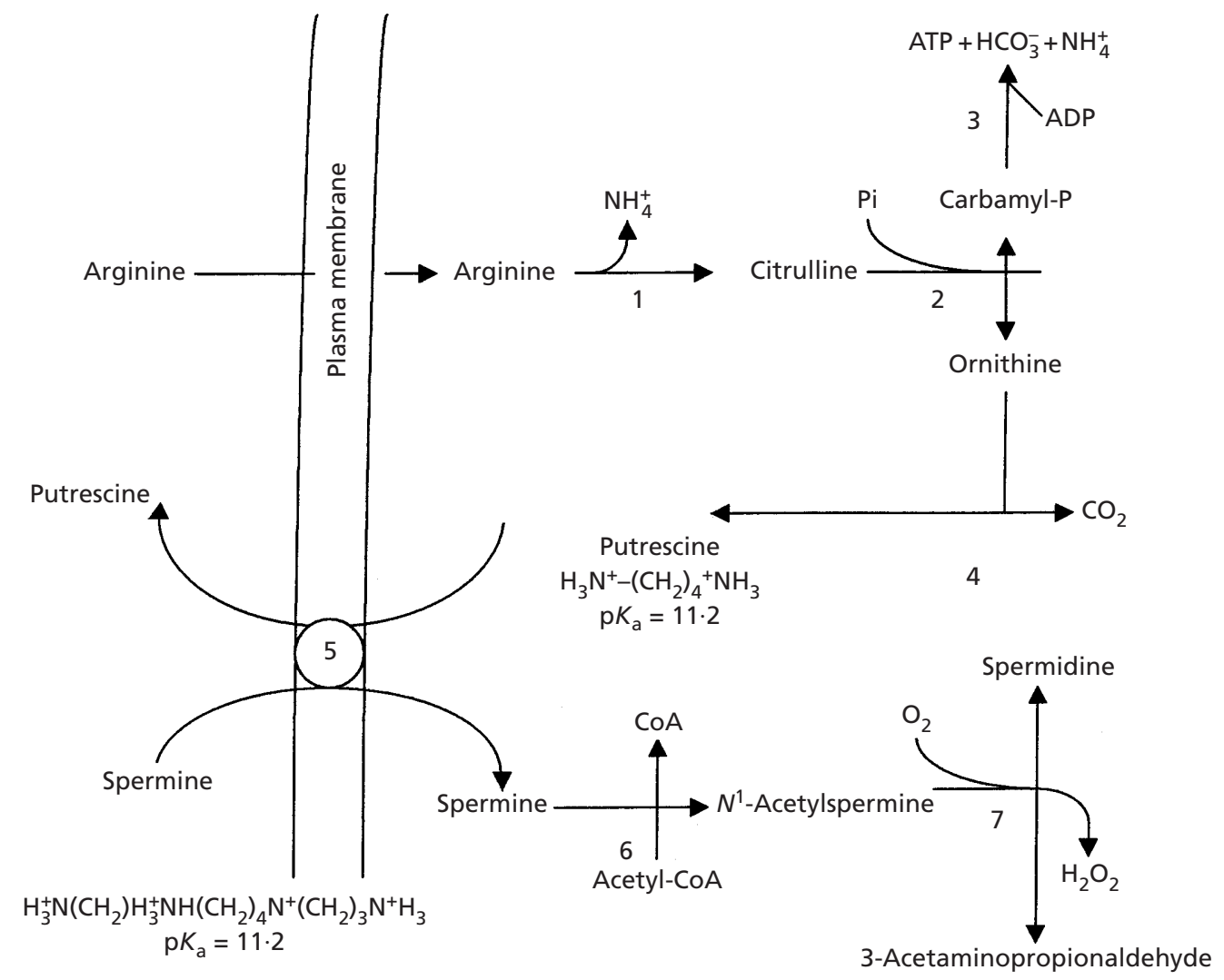

Fig. 1. Polyamine transport and backconversion by $T$. vaginalis. 1 , Arginine deiminase; 2 , catabolic ornithine carbamyltransferase; 3, carbamate kinase; 4, ornithine decarboxylase; 5, putrescine:spermine antiporter; 6, SSAT; 7, polyamine oxidase. Two putrescines are required to antiport with one spermine to balance the charge transfer.

polyamine (or diamine) auxotrophy may be a common adaptation amongst parasites.

In this study we are able to demonstrate that the spermine taken up by the trichomonads is backconverted to spermidine, via a spermidine: spermine $\mathrm{N}^{1}$ acetyltransferase (SSAT)/polyamine oxidase coupled pathway. SSAT catalyses the transfer of an acetyl group from acetyl-CoA to a terminal aminopropyl nitrogen of spermine or spermidine forming $N^{1}$-acetyl spermine or $N^{1}$-acetyl spermidine, respectively, which in turn are metabolized to spermidine and putrescine by the action of polyamine oxidases (Fig. 1). In mammalian cells these enzymes are constitutively present at low levels, but are highly inducible by certain agents such as thioacetamide and certain polyamine analogues such as di(ethyl) spermidine and di(ethyl)norspermine (DENSpm) (Erwin \& Pegg, 1986; Libby et al., 1989). It has been hypothesized that bis(alkyl) polyamine analogues inhibit the growth of mammalian cells by increasing backconversion and export of the natural polyamines, and by acting as functionless equivalents of the natural polyamines (Erwin \& Pegg, 1986; Libby et al., 1989). We demonstrate in this study that growth of T. vaginalis with DENSpm also results in polyamine depletion and significant inhibition of growth by a mechanism that involves competition with the transport of spermine and inhibition of SSAT effectively blocking spermidine synthesis.

\section{METHODS}

Cell cultures. T. vaginalis C1 (ATCC 30001) cultures were grown at $37^{\circ} \mathrm{C}$ for $24 \mathrm{~h}$ in tryptose/yeast extract/maltose medium, pH 6.2, without agar and with $10 \%$ heat-inactivated horse serum (Diamond, 1957). Cultures were harvested by centrifugation at $920 \mathrm{~g}$ for $5 \mathrm{~min}$ at $4{ }^{\circ} \mathrm{C}$ in a GSA rotor of a refrigerated RC-2B centrifuge (Sorvall). Cells were washed in a phosphate-buffered salts solution consisting of $30 \mathrm{mM}$ phosphate buffer ( $\mathrm{pH} 7 \cdot 4$ ) containing $74 \mathrm{mM} \mathrm{NaCl}, 0.6 \mathrm{mM}$ $\mathrm{CaCl}_{2}$ and $1.6 \mathrm{mM} \mathrm{KCl}$, and resuspended in this buffer for disruption using a Potter-Elvehjem homogenizer (30 strokes). Unbroken cells and nuclei were removed by centrifugation at $400 \mathrm{~g}$ for $4 \mathrm{~min}$ at $4{ }^{\circ} \mathrm{C}$ in the RC-2B centrifuge equipped with an SS-34 rotor. Homogenates were dialysed overnight against $1110 \mathrm{mM}$ Tris $/ \mathrm{HCl}, \mathrm{pH} 7 \cdot 4$, at $4{ }^{\circ} \mathrm{C}$ with two changes of buffer.

Subcellular fractionation. Cell pellets were resuspended in $10 \mathrm{mM}$ Tris/ $\mathrm{HCl}$ buffer (pH 7.4) containing $225 \mathrm{mM}$ sucrose, $1 \mathrm{mM} \mathrm{CaCl}_{2}$ and $1 \mathrm{mM} \mathrm{MgCl}_{2}$, and broken by 35 strokes in a Potter-Elvehjem tissue homogenizer at $4{ }^{\circ} \mathrm{C}$. The broken cells were diluted in isotonic buffer and centrifuged at $400 \mathrm{~g}$ for 10 min, resulting in nuclear and cell-free extract fractions. The cell-free extract was further fractioned by centrifugation, yielding a large granular fraction $(2200 \mathrm{~g}, 10 \mathrm{~min})$, a small 
granular fraction $(28000 \mathrm{~g}, 30 \mathrm{~min})$ and a final cytosolic fraction (Lindmark \& Müller, 1973). The fractions were characterized by use of the following marker enzymes: malic enzyme (LGF), acid phosphatase (SGF) and lactate dehydrogenase (cytosol), which were assayed as described by Lindmark \& Muller (1973). The integrity of the particles was demonstrated using $0 \cdot 1 \%$ Triton X-100.

Enzyme analysis. SSAT and spermidine $N^{1}$-acetyltransferase activities were determined by measuring the incorporation of radioactivity from labelled acetyl-CoA into monoacetylspermine or monoacetylspermidine, respectively. The radiolabelled monoacetylpolyamine product was dried on cellulose phosphate paper discs and exhaustively washed to remove unused $\left[{ }^{14} \mathrm{C}\right]$ acetyl-CoA. The assay was performed in incubations containing $0.5 \mathrm{mM}$ Bicine $(\mathrm{pH} 8 \cdot 0), 16.5 \mu \mathrm{M}$ [1${ }^{14} \mathrm{C}$ ]acetyl-CoA $\left(60 \mu \mathrm{Ci} \mathrm{mmol}{ }^{-1}\right), 1 \mathrm{mM}$ acetyl-CoA, $0 \cdot 05-$ $10 \mathrm{mM}$ spermidine or spermine and $25 \mu$ l dialysed cell-free extract $(50-100 \mu \mathrm{g}$ protein) in a final volume of $200 \mu \mathrm{l}$ for $60 \mathrm{~min}$ at $37^{\circ} \mathrm{C}$. The reaction was stopped with $20 \mu \mathrm{l}$ ice cold $0.5 \mathrm{M}$ hydroxylamine, boiled for $3 \mathrm{~min}$, microfuged $(12500 \mathrm{~g}$ for $1 \mathrm{~min}$ ) and applied to cellulose phosphate discs (Whatman P81). The filters were washed thoroughly with distilled water and finally flushed with methanol prior to drying. Radioactivity was determined using a Beckman TriCarb 1600 CA liquid scintillation counter (Hewlett Packard).

Polyamine oxidase activity was determined by two separate methods; the first measured the spermine-dependent formation of hydrogen peroxide. The peroxide released was detected by measuring the production of tetraguaiacol from guaiacol (2-methoxyphenol) at $420 \mathrm{~nm}$. The assay contained $10 \mathrm{mM}$ glycine $(\mathrm{pH} 8.0), 10 \mathrm{mM}$ guaiacol, $5 \mathrm{U}$ horseradish peroxidase and $50-100 \mu \mathrm{g}$ dialysed T. vaginalis protein ; $1 \mathrm{mM}$ $N^{1}$-acetylspermine or $1 \mathrm{mM}$ spermine with $0.5 \mathrm{mM}$ CoA was added to start the reaction. The second method employed measuring the absorbance change at $450 \mathrm{~nm}$ in a buffer containing $10 \mathrm{mM}$ glycine (pH 8.0), $50 \mu \mathrm{M}$ FAD and 50-100 $\mu \mathrm{g}$ dialysed $T$. vaginalis protein. The reaction was started by adding $1 \mathrm{mM} N^{1}$-acetylspermine or $1 \mathrm{mM}$ spermine with $0.5 \mathrm{mM}$ CoA. Protein was determined by the Lowry method.

Inhibition of polyamine biosynthesis. The effect of DENSpm on growth and polyamine biosynthesis was determined by inoculating $1.5 \times 10^{6}$ cells into $10 \mathrm{ml}$ fresh culture media containing $50 \mu \mathrm{M}$ of the compound. After $16 \mathrm{~h}$, the cells were counted using a haemocytometer and compared to the growth of control cultures containing no DENSpm. The cells were harvested by centrifugation at $920 \mathrm{~g}$ for $5 \mathrm{~min}$ at room temperature and washed with phosphate-buffered salts solution. The cell pellets were lysed with $6 \%$ trichloroacetic acid and stored at $-80^{\circ} \mathrm{C}$ until analysed by HPLC. Polyamines were separated on a C-18 $10 \mu \mathrm{m}$ column $(4.5 \times 250 \mathrm{~mm})$ using a series LC 410 pump (Perkin-Elmer) fitted with a rheodyne $50 \mu$ loop injector at a flow rate of $1 \mathrm{ml} \mathrm{min}^{-1}$. Standards and samples were precolumn derivatized by mixing with 2 vols $O$ phthaldialdehyde and separated using a discontinuous gradient of $12 \mathrm{mM}$ lithium citrate containing $1 \mathrm{mM}$ octanesulfonic acid ( $\mathrm{pH} 2.65)$ and eluted using acetonitrile (Yarlett \& Bacchi, 1988). Samples and standards were analysed using a fluorescence monitor (excitation wavelength $320 \mathrm{~nm}$, emission wavelength $455 \mathrm{~nm}$ ) (Perkin-Elmer). Areas under the peak were determined using a $\beta$-Ram computer software program (IN/US Systems).

Polyamine uptake and metabolism. The ability of T.vaginalis to transport and metabolize ornithine, putrescine and spermine was determined in $10 \mathrm{ml}$ semi-defined growth medium
(Yarlett \& Bacchi, 1988), containing $5 \mu \mathrm{M}\left[2,3-{ }^{3} \mathrm{H}\right]$ ornithine $(10 \mu \mathrm{Ci}), 0 \cdot 18 \mu \mathrm{M}\left[1,4-{ }^{14} \mathrm{C}\right]$ putrescine $(1 \mu \mathrm{Ci})$ or $0 \cdot 09 \mu \mathrm{M}[4,7-$ $\left.{ }^{14} \mathrm{C}\right]$ spermine $(0.5 \mu \mathrm{Ci})$. Cultures were inoculated with $1.5 \times 10^{6}$ parasites, incubated for $16 \mathrm{~h}$, and the cells counted and harvested by centrifugation at $1000 \mathrm{~g}$ for $5 \mathrm{~min}$ (Sorvall RTB centrifuge; DuPont). The cells were washed once in phosphate-buffered salts solution and lysed with 6\% TCA at $4{ }^{\circ} \mathrm{C}$. Denatured protein was removed by centrifugation and the supernatant filtered through a $0.45 \mu \mathrm{m}$ Acrodisc filter (Gelman) prior to analysis. Polyamines were separated by ionpaired reverse-phase HPLC using a Perkin Elmer series 410 pump fitted with a Rheodyne $50 \mu$ loop injector. Samples and standards were separated on a C-18 Percosil column $(4.6 \times 250$ $\mathrm{mm}$ ) using a linear gradient consisting of $0 \cdot 1 \mathrm{M} \mathrm{NaH}_{2} \mathrm{PO}_{4}, 2 \%$

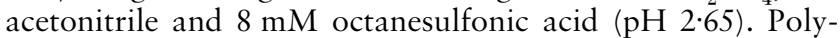
amines were eluted with $150 \mathrm{mM} \mathrm{NaH} \mathrm{PO}_{4}, 26 \%$ acetonitrile and $8 \mathrm{mM}$ octanesulfonic acid (pH 3.25) (Yarlett et al., 1994). Samples were analysed using a flow-through model 1B Radiometric detector (IN/US Systems) which mixed three parts scintillant (INFLOW ES) to one part sample. Signals were integrated using $\beta$-Ram computer software version 1.62 (IN/US Systems).

Calculation of data. Michaelis-Menten kinetics were used to analyse the enzyme-substrate interactions (Segal, 1976). Enzyme activities and $K_{\mathrm{m}}$ values were derived using HanesWoolf analysis of substrate plots using Grafit computer software (Erithacus Software). Hanes-Woolf analysis was selected because it enables a more accurate determination of $K_{\mathrm{m}}$ in a crude homogenate (Segal, 1976). The $K_{\mathrm{m}}$ is defined as the substrate concentration at which the initial reaction velocity is half maximal. The inhibition of SSAT by DENSpm was analysed by Eadie-Hofstee plots and the $K_{\mathrm{i}}$ determined from analysis of variation in $K_{m}$ versus increasing inhibitor concentration. This analysis results in a more accurate approximation of $K_{\mathrm{i}}$ as $K_{\mathrm{m}}$ is unaffected by protein content (Segal, 1976). The results are presented as the mean \pm sample standard deviation (SD) of the coordinate values in the matrix.

Chemicals. Radioactive substrates were obtained from DuPont. DENSpm was a gift from the National Cancer Institute. All other chemicals were from Sigma.

\section{RESULTS}

\section{SSAT}

SSAT activity was detected in crude extracts of $T$. vaginalis by measuring the acetylation of exogenously supplied spermidine and spermine using $\left[1-{ }^{14} \mathrm{C}\right]$ acetylCoA. The enzyme had a $\mathrm{pH}$ optimum of 8.0 for both substrates and exhibited Michaelis-Menten kinetics. Hanes-Woolf analysis of the substrate curve for SSAT with spermine resulted in a linear plot with a maximal activity at a saturating spermine concentration of $0.39 \pm 0.09 \mathrm{nmol} \mathrm{min}{ }^{-1}$ (mg protein) ${ }^{-1}$ (the mean of five determinations), and an apparent $K_{\mathrm{m}}$ of $1.7 \mu \mathrm{M}$ for spermine. The activity with spermidine as substrate was $0.03 \pm 0.007 \mathrm{nmol}$ spermidine $\min ^{-1}(\mathrm{mg} \text { protein })^{-1}$ (the mean of five determinations), and Hanes-Woolf analysis of the spermidine substrate curve resulted in an apparent $K_{\mathrm{m}}$ of $14 \mu \mathrm{M}$. The activity of the trichomonad SSAT was competitively inhibited in a dose-dependent manner by DENSpm with an apparent $K_{\mathrm{i}}$ of $28 \mu \mathrm{M}$, as determined from Eadie-Hofstee analysis of $K_{\mathrm{m}}$ versus inhibitor concentration (Fig. 2). 

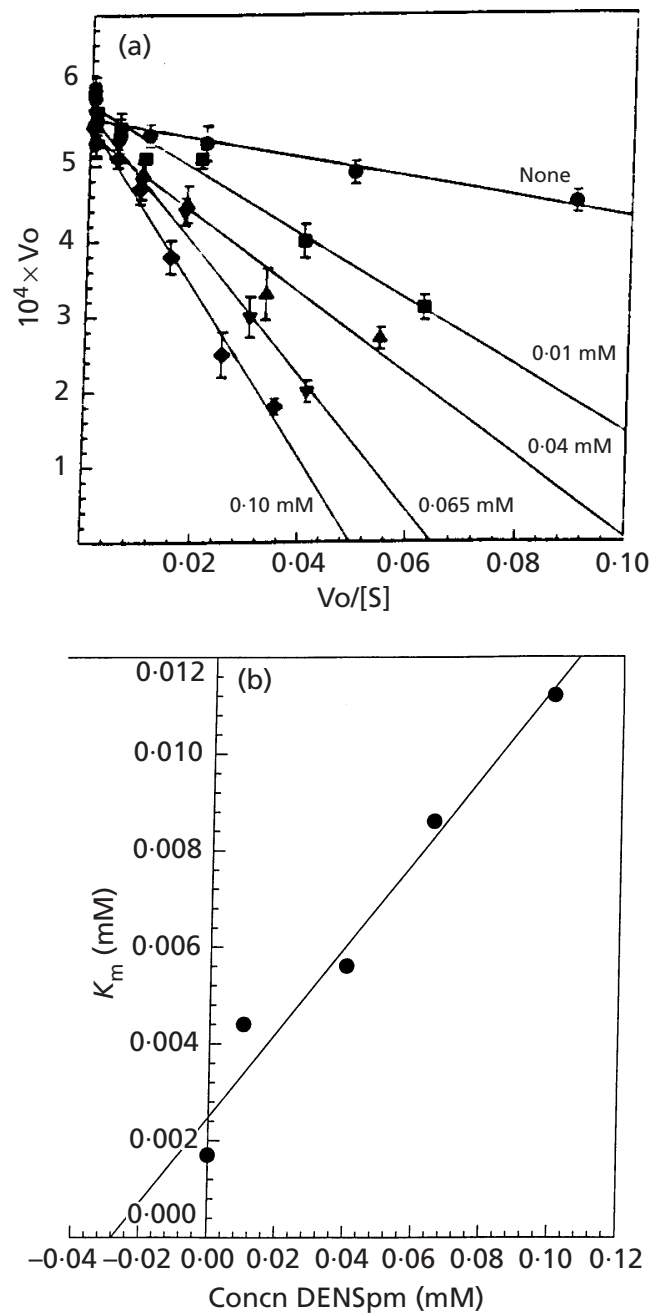

Fig. 2. Inhibition of SSAT by DENSpm. (a) WoolfAugustinsson-Hofstee plot. The kinetics of DENSpm inhibition were analysed in incubations containing $16.5 \mu \mathrm{M}\left[1-{ }^{14} \mathrm{C}\right]$ acetylCoA $(0.1 \mu \mathrm{Ci})$ plus $1 \mathrm{mM}$ acetyl-CoA and varying concentrations of spermine $(0.05-10 \mathrm{mM})$, and increasing DENSpm concentrations: $0 \mathrm{mM}(\mathbf{0}), 0.01 \mathrm{mM}(\boldsymbol{\nabla}), 0.04 \mathrm{mM}(\boldsymbol{\Delta}), 0.065 \mathrm{mM}(\boldsymbol{\nabla})$ and $0.10 \mathrm{mM}(\diamond)$. (b) The $K_{\mathrm{i}}$ was determined to be $28 \mu \mathrm{M}$ by Dixon plot analysis of Eadie-Hofstee plots.

\section{Effect of DENSpm on polyamine metabolism}

The effect of DENSpm on growth, enzyme activity and total polyamine content was determined in cells incubated overnight $(16 \mathrm{~h})$ in growth media containing $50 \mu \mathrm{M}$ DENSpm. Cell counts indicated a $66 \%$ reduction in the growth of DENSpm-containing cultures $\left(0 \cdot 82 \times 10^{6}\right.$ cells $\left.\mathrm{ml}^{-1}\right)$, compared to control cultures lacking this compound $\left(2 \cdot 4 \times 10^{6}\right.$ cells ml $\left.{ }^{-1}\right)$. The activity of SSAT and ornithine decarboxylase (ODC) was determined in cells grown in the presence of DENSpm and compared to controls. Cells incubated with DENSpm had lowered activity of both these enzymes (Table 1). Consistent with reduced SSAT activity, intracellular spermidine levels were $69 \%$ reduced, and a minor $(10 \%)$ reduction in putrescine was also observed
(Table 1). The intracellular concentration of spermine was also significantly reduced $(83 \%)$ (Table 1$)$. The total pool of DENSpm plus spermine in treated cells was found to be $3.7 \mathrm{nmol}$ per $10^{7}$ cells, which is similar to the spermine pool of $3.5 \mathrm{nmol}$ per $10^{7}$ cells in control cells.

\section{Polyamine oxidase}

Polyamine oxidase activity was detected in crude extracts of $T$. vaginalis. The enzyme was dependent upon addition of $N^{1}$-acetylspermine. Due to the presence of SSAT in crude homogenates, polyamine oxidase activity could also be demonstrated in assays containing acetyl-CoA and spermine. Kinetic analysis of the T. vaginalis polyamine oxidase with FAD as cofactor and $N^{1}$-acetylspermine as substrate resulted in a linear Hanes-Woolf plot, with a maximum activity in the presence of saturating $N^{1}$-acetylspermine of $1 \cdot 28 \pm 0.07 \mathrm{nmol} \mathrm{N}{ }^{1}$-acetylspermine oxidized $\mathrm{min}^{-1}$ ( $\mathrm{mg}$ protein $)^{-1}$ (the mean of five determinations), and an apparent $K_{\mathrm{m}}$ for $N^{1}$-acetylspermine of $6 \cdot 0 \mu \mathrm{M}$.

Polyamine oxidase activity was also determined in crude extracts by measuring the formation of peroxide, a product of the oxidase, in incubations containing guaiacol and horseradish peroxidase. The assay measures the formation of tetraguaiacol $\left(A_{420}\right)$ from guaiacol, which occurs in the presence of $\mathrm{O}^{*}$ liberated from $\mathrm{H}_{2} \mathrm{O}_{2}$ by the action of peroxidase. The formation of tetraguaiacol from guaiacol by the trichomonad polyamine oxidase was dependent upon the addition of CoA and spermine. In the absence of added peroxidase a minor endogenous rate $(<10 \%$ of that with added peroxidase) was obtained, suggesting the presence of a minor amount of endogenous peroxidase activity in $T$. vaginalis. Interference due to the presence of catalase can be ruled out as this enzyme has previously been shown to be absent from this parasite (Müller, 1989). Addition of spermine or CoA alone resulted in minor rates $\left[0.14\right.$ and $0.09 \mathrm{nmol} \mathrm{min}{ }^{-1}(\mathrm{mg} \text { protein })^{-1}$, respectively] until both were added to the reaction mixture $\left.\left[0.47 \mathrm{nmol} \mathrm{min}^{-1} \text { (mg protein) }\right)^{-1}\right]$.

\section{Polyamine interconversion}

This series of experiments investigated the uptake and metabolism of radiolabelled polyamines and polyamine precursors. T. vaginalis was grown for $16 \mathrm{~h}$ in a semidefined medium containing $5 \mu \mathrm{M}\left[2,3{ }^{3} \mathrm{H}\right]$ ornithine, $0 \cdot 18 \mu \mathrm{M} \quad\left[1,4-{ }^{14} \mathrm{C}\right]$ putrescine or $0 \cdot 09 \mu \mathrm{M} \quad\left[4,7-{ }^{14} \mathrm{C}\right]-$ spermine and analysed for radiolabelled polyamine content. HPLC analysis of acid extracts of cells grown in the presence of radiolabelled ornithine shows that ornithine is taken up ( $250 \mathrm{pmol}$ per $10^{7}$ cells $)$, and is converted by ODC to putrescine $\left(340\right.$ pmol per $10^{7}$ cells). However, putrescine was not further metabolized to spermidine or spermine (Fig. 3a). The presence of $5 \mathrm{mM}$ difluoromethylornithine, a suicide inhibitor of ODC, reduced the intracellular amount of putrescine to 70 pmol per $10^{7}$ cells $(79 \%$ inhibition; Fig. 3b). Likewise, 
Table 1. Polyamine, ODC and SSAT levels in T. vaginalis

Cells were treated with $50 \mu \mathrm{M}$ DENSpm. All cells were grown in semi-synthetic medium (Yarlett \& Bacchi, 1988). Cells $\left(10^{9}\right)$ were harvested and homogenates made in phosphate-buffered salts solution by three freeze-thaw cycles. ODC and SSAT activity is expressed as nmol product formed $\min ^{-1}$ (mg protein $)^{-1}$. Polyamine levels are expressed as nmol per $10^{7}$ cells. ODC was measured as described by Yarlett et al. (1993), SSAT was assayed as described by Libby et al. (1989), polyamines were assayed as described by Yarlett \& Bacchi (1988). The enzyme data are presented as means \pm SD of five separate experiments, the polyamine levels are presented as means \pm SD of triplicate experiments.

\begin{tabular}{|lccc|}
\hline Compound/enzyme & Control cells & Treated cells & Reduction (\%) \\
\hline Putrescine & $117 \cdot 0 \pm 28$ & $104 \cdot 9 \pm 12 \cdot 0$ & 10 \\
Spermidine & $5 \cdot 04 \pm 2 \cdot 1$ & $1 \cdot 58 \pm 0 \cdot 8$ & 69 \\
Spermine & $3 \cdot 5 \pm 1 \cdot 7$ & $0 \cdot 58 \pm 0 \cdot 3$ & 83 \\
DENSpm & 0 & $3 \cdot 2 \pm 0 \cdot 7$ & - \\
ODC & $0 \cdot 22 \pm 0 \cdot 06$ & $0 \cdot 13 \pm 0 \cdot 1$ & 41 \\
SSAT & $0 \cdot 39 \pm 0 \cdot 09$ & $0 \cdot 17 \pm 0 \cdot 05$ & 56 \\
\hline
\end{tabular}
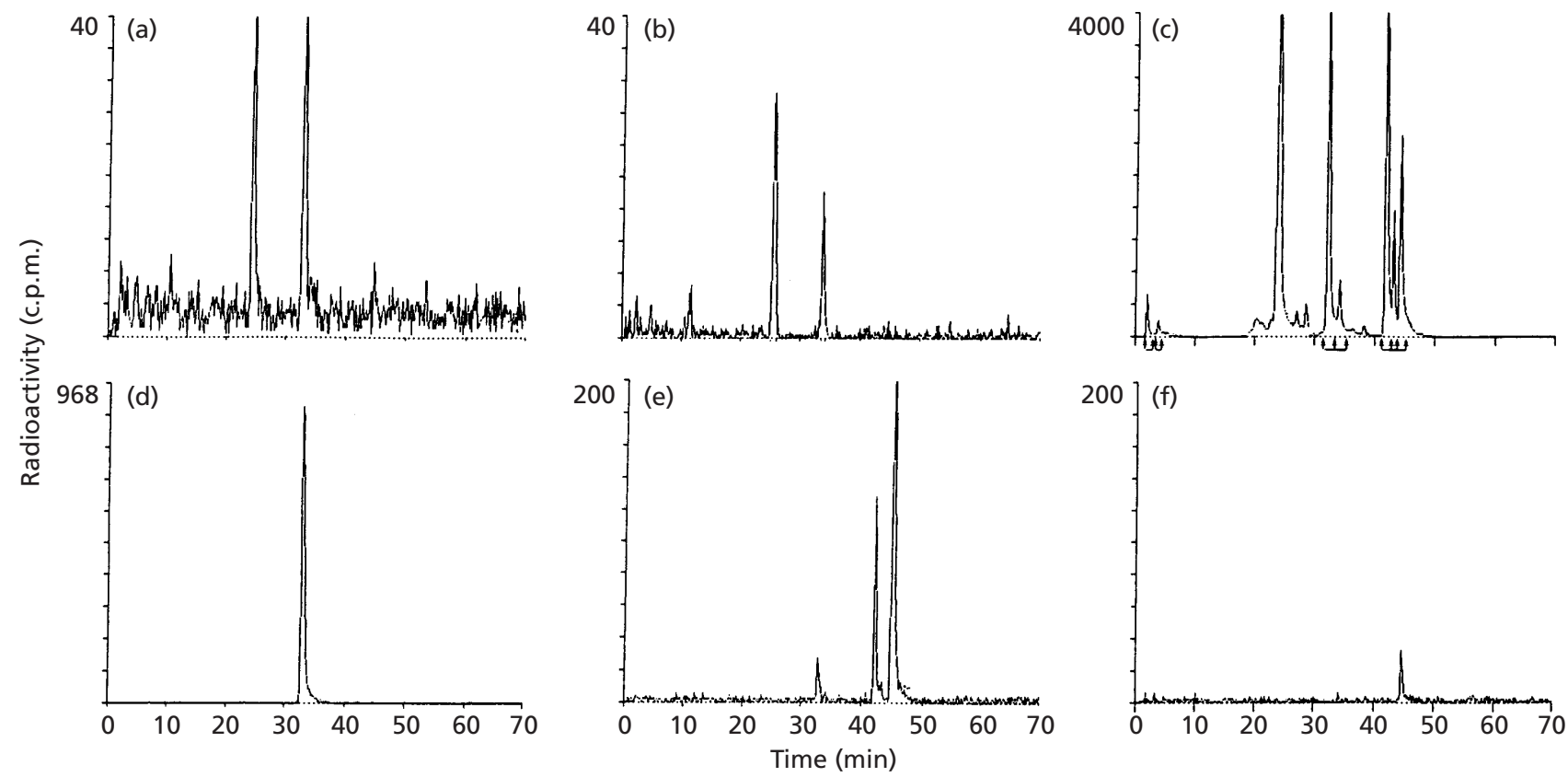

Fig. 3. Metabolism of spermine and putrescine by $T$. vaginalis whole cells. Cells were grown for $16 \mathrm{~h}$ in semi-defined medium (Yarlett \& Bacchi, 1988) containing the specified radiolabelled amine. The amount of intracellular label is given in parenthesis as pmol per $10^{7}$ cells. (a) $5 \mu \mathrm{M}\left[2,3-{ }^{3} \mathrm{H}\right]$ ornithine (ornithine 250 , putrescine 340 ); (b) $5 \mu \mathrm{M}\left[2,3-{ }^{3} \mathrm{H}\right]$ ornithine plus $5 \mathrm{mM}$ difluoromethylornithine (ornithine 184, putrescine 70); (d) $0.18 \mu \mathrm{M}\left[1,4-{ }^{14} \mathrm{C}\right]$ putrescine (putrescine 70); (e) $0.09 \mu \mathrm{M}\left[4,7-{ }^{14} \mathrm{C}\right]$ spermine (putrescine $1 \cdot 4$, spermidine 6 , spermine 26 ); (f) $0.09 \mu \mathrm{M}\left[4,7-{ }^{14} \mathrm{C}\right]$ spermine plus $50 \mu \mathrm{M}$ DENSpm (spermine 1.4). Cells were counted, harvested, washed and extracted with $6 \%(\mathrm{v} / \mathrm{v})$ trichloroacetic acid. Polyamines were separated by HPLC and analysed by radiometric detection as described in Methods. (c) Standards: 125 pmol ornithine (retention time $23.4 \mathrm{~min}$ ), $900 \mathrm{pmol}$ putrescine (retention time $32.0 \mathrm{~min}$ ), 120 pmol spermidine (retention time $41.4 \mathrm{~min}$ ), $450 \mathrm{pmol}$ spermine (retention time $44.0 \mathrm{~min}$ ).

putrescine was readily taken up by T.vaginalis (Fig. 3d), reaching 70 pmol per $10^{7}$ cells, and again no conversion to the higher polyamines was detected. These data are in agreement with previous results which failed to detect $S$-adenosyl-L-methionine decarboxylase activity and a forward-directed polyamine biosynthetic pathway in this parasite (Yarlett, 1988). In contrast, radiolabelled spermine was taken up (26 pmol per $10^{7}$ cells $)$ and converted to spermidine $\left(6\right.$ pmol per $10^{7}$ cells $)$ and putrescine $\left(1.4 \mathrm{pmol}\right.$ per $10^{7}$ cells; Fig. $\left.3 \mathrm{e}\right)$. The presence of $50 \mu \mathrm{M}$ DENSpm reduced the amount of radiolabelled spermine taken up by $95 \%\left(1.4 \mathrm{pmol}\right.$ per $10^{7}$ cells $)$ and completely blocked backconversion to spermidine and putrescine (Fig. 3f). These results demonstrate that 


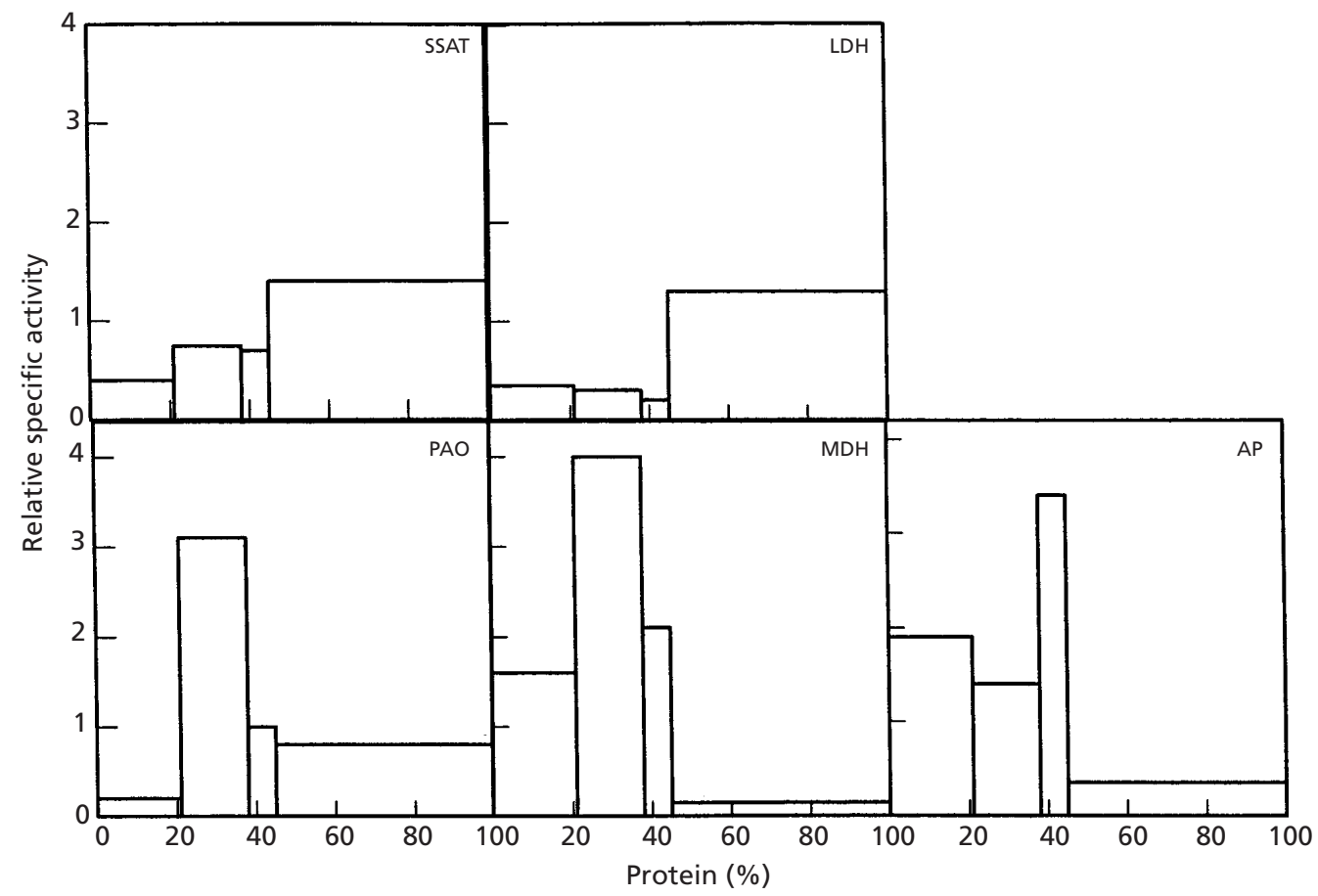

Fig. 4. Subcellular localization of polyamine backconversion enzymes in $T$. vaginalis. The results represent a typical experiment of triplicate repeats. Homogenates of $T$. vaginalis were subjected to differential centrifugation, with increasing gravitational force from left to right. Enzymes were assayed as described in Methods and plotted as relative specific activity versus percentage protein. Recovery of enzymes were: SSAT $89 \%$; lactate dehydrogenase (LDH) $87 \%$; polyamine oxidase (PAO) $95 \%$; malate dehydrogenase decarboxylating (MDH) $92 \%$; acid phosphatase (AP) $97 \%$; protein recovery was $94 \%$.

polyamine uptake and backconversion is a constitutive feature of these cells.

\section{Subcellular distribution of polyamine oxidase/SSAT enzymes}

Subcellular fractionation of $T$. vaginalis extracts resulted in typical distribution profiles for marker enzymes: malate dehydrogenase [decarboxylating] (large granular fraction), acid phosphatase (small granular fraction and lactate dehydrogenase (cytosolic fraction) (Lindmark \& Müller, 1974). A major portion of the polyamine oxidase was associated with the large granular fraction and a lesser but significant amount was associated with the cytosolic fraction (Fig. 4). The subcellular distribution profile for SSAT demonstrated that the majority of the enzyme was cytosolic (Fig. 4).

\section{DISCUSSION}

Polyamine oxidation and backconversion is performed by diverse cell types including animal, plant and prokaryotes (Cohen, 1998), and is presumed to function in regulating intracellular polyamine levels. The amine oxidases are classified according to their cofactor requirements. The mitochondrial monoamine oxidases and the polyamine oxidases are FAD-requiring enzymes, whereas mammalian serum amine oxidases and the diamine oxidases are copper-dependent enzymes (Seiler, 1987; Mondovi et al., 1988). As found in other eukaryotes (Seiler, 1987) the trichomonad polyamine oxidase used $\mathrm{FAD}^{+}$as a cofactor. The rate of $\mathrm{N}^{1}$ acetylspermine oxidation was determined to be fivefold greater than the rate of formation of $N^{1}$-acetylspermine, suggesting that this intermediate does not accumulate in the cell, but rapidly proceeds to spermidine. In the majority of cells, the degradation of acetyl spermine liberates the aminopropyl group as acetamidopropanal (Seiler, 1987). The aminopropyl product of the $T$. vaginalis polyamine oxidase has not been identified, but is likely to be acetamidopropanal also, because this can be further metabolized to alanine and $\delta$-pyrroline, which are present in high concentrations in $T$. vaginalis (Chapman et al., 1985; Knodler et al., 1994). The presence of acetamidopropanal and its further catabolism to alanine by $T$. vaginalis is currently being investigated. Spermidine is slowly metabolized further by the $T$. vaginalis enzymes to produce a product that elutes at the same retention time as putrescine. However, the system used for this analysis cannot distinguish between 1,4-diaminobutane (putrescine) or 1,3-diaminopropane. 1,3-Diaminopropane is a product of spermidine degradation by polyamine oxidase from plants (Federico et al., 1996), bacteria (Tabor \& Tabor, 1984) and Acanthamoeba spp. (Kim et al., 1987). We have evidence that 1,3-diaminopropane is also a minor 
product of polyamine metabolism by $T$. vaginalis $(\mathrm{N}$. Yarlett \& A. Bitonti, unpublished). The formation of these compounds results in irreversible removal of the amine group from the polyamine pathway, hence polyamine oxidation can be considered as the terminal step in catabolism of polyamines.

The subcellular distribution of SSAT and polyamine oxidase indicates that they are in separate subcellular compartments. The predominantly cytosolic location of SSAT would enable spermine, taken up by the putrescine: spermine antiporter system (Yarlett \& Bacchi, 1994), to be acetylated. Acetylation of polyamines neutralizes the charge on the polyamine and enhances transport. This processing of spermine may be necessary to enable entry of spermine into subcellular compartments such as nuclei where it may then be deacetylated, liberating free spermine. The predominantly hydrogenosomal location of the polyamine oxidase suggests that acetylation of spermine is also necessary for entry of spermine into this organelle, where it is further metabolized by the polyamine oxidase, releasing spermidine. That acetylation has a significant role in hydrogenosome metabolism is corroborated by the significant ultrastructural damage that occurs to these organelles when polyamine metabolism is blocked by use of polyamine analogues, such as diaminobutanone or DENSpm (Reis et al., 1999; Santoro et al., 1999). Previous localization studies with mammalian cells have demonstrated that polyamine oxidase is also localized in subcellular compartments (Pavlov et al., 1991; Holta, 1977).

SSAT is the first and rate-limiting step in the backconversion pathway of polyamine metabolism (Casero \& Pegg, 1993; Woster, 1993). The enzyme acetylates the aminopropyl end of spermine or spermidine, thus reducing the charge on the polyamine. In mammalian cells, SSAT has been characterized as being highly substrate specific, rapidly inducible and having a short half-life (Woster, 1993). The enzyme is rapidly induced in mammalian cells by a variety of factors including polyamine analogues, such as DENSpm (Porter et al., 1991). Acetylated polyamines can then act as a substrate for polyamine oxidase or can be excreted (Woster, 1993; Wallace, 1987) which also results in downregulation of polyamine biosynthetic enzymes and suppression of polyamine transport. The net effect of the bis(alkyl) polyamine analogues is to deplete intracellular polyamines and thereby inhibit cell growth (Porter $\mathrm{et}$ al., 1991; Casero et al., 1989; Pegg et al., 1989). In contrast to mammalian cells, where an SSAT induction of 200- to 1000-fold was observed (Porter et al., 1991; Casero et al., 1989; Pegg et al., 1989), the trichomonad enzyme was not induced by $16 \mathrm{~h}$ in vitro culture with $50 \mu \mathrm{M}$ DENSpm.

Acetylation, particularly $N^{1}$-acetylspermidine, may enhance polyamine excretion since acetylated polyamines are typically found outside of the cell, not within it (Wallace, 1987). Growth inhibition in mammalian cell lines by DENSpm is believed to be the result of super induction of SSAT, which results in increased $N^{1}$ - acetylspermidine production which is then apparently excreted into the medium (Pegg et al., 1989); thus SSAT may be a determinant in polyamine export (Porter et al., 1991). Consistent with this hypothesis is the observation that murine L1210 and B16 melanoma cell lines which do not superinduce SSAT maintain a nitrogen (or charge) equivalent balance between analogue uptake and polyamine depletion (Libby et al., 1989; Bergeron et al., 1989). In this study it was found that DENSpm caused a significant reduction of trichomonad intracellular polyamines. Based upon a mean intracellular volume of 47-60 $\mu \mathrm{l}$ per $10^{8}$ cells (Knodler et al., 1994), it can be calculated that the intracellular concentration of DENSpm reaches $75-90 \mu \mathrm{M}$. This is approximately 1.5-2 times the extracellular concentration, and well above the $K_{\mathrm{i}}$ for SSAT. These findings suggest that $T$. vaginalis is able to concentrate polyamines (and their analogues) against a concentration gradient. The mode of action of DENSpm in T. vaginalis appears to involve competition with spermine for transport into the cell (Yarlett \& Bacchi, 1994), and, once internalized, to block backconversion of spermine to spermidine by inhibition of SSAT. This is borne out by the observation that the total tetra-amine pool size (spermine plus DENSpm) of treated and untreated cells are essentially unchanged. Hence, consistent with the proposed mode of action, the greatest effect of DENSpm is on the trichomonad spermidine pool, which is decreased $68 \%$ in treated cells. These results clearly demonstrate the potential of this pathway as a rational target for the future design of antitrichomonad agents.

\section{ACKNOWLEDGEMENTS}

The authors thank Ms Elaine Manios and Ms Tuesday Cook for expert technical assistance. This research was supported by grant AI 25361 from the National Institute of Allergy and Infectious Diseases (NY).

\section{REFERENCES}

Ariyanayagan, M. R. \& Fairlamb, A. H. (1997). Diamine auxotrophy may be a universal feature of Trypanosoma cruzi epimastigotes. Mol Biochem Parasitol 84, 111-121.

Bergeron, R. J., Hawthorne, T. R., Vinson, J. R. T., Beck, D. E., Jr \& Ingeno, M. J. (1989). Role of the methylene backbone in the antiproliferative activity of polyamine analogues on L1210 cells. Cancer Res 49, 2959-2964.

Casero, R. A., Jr \& Pegg, A. E. (1993). Spermidine/spermine $N^{1}$ acetyltransferase - the turning point in polyamine metabolism. FASEB J 7, 653-661.

Casero, R. A., Jr, Celano, P., Ervin, S. J., Porter, C. W., Bergeron, R. J. \& Libby, P. R. (1989). Differential induction of spermidine/ spermine $N^{1}$-acetyltransferase in human lung cancer cells by the bis(ethyl) polyamine analogues. Cancer Res 49, 3829-3833.

Chapman, A., Linstead, D. J., Lloyd, D. \& Williams, J. (1985). ${ }^{13} \mathrm{C}-$ NMR reveals glycerol as an unexpected major metabolite of the protozoan parasite Trichomonas vaginalis. FEBS Lett 191, 287-292.

Cohen, S. (1998). Polyamine oxidases and dehydrogenases: In $A$ Guide to the Polyamines, pp. 69-93. New York: Oxford University Press. 
Diamond, L. (1957). The establishment of various trichomonads of animals and man in axenic cultures. J Parasitol 43, 488-490.

Erwin, B. G. \& Pegg, A. E. (1986). Regulation of spermidine/ spermine $N^{1}$-acetyltransferase in L6 cells by polyamines and related compounds. Biochem J 238, 581-587.

Federico, R., Ercolini, L., Laurenzi, M. \& Angelini, R. (1996). Oxidation of acetylpolyamines by maize polyamine oxidase. Phytochemistry 43, 339-341.

Feurstein, B. G., Pattabiraman, N. \& Marton, L. J. (1990). Molecular mechanisms of the interactions of spermine with DNA: DNA bending as a result of ligand binding. Nucleic Acids Res 18, 1271-1277.

Ha, H. C., Woster, P. M., Yager, J. D. \& Casero, R. A., Jr (1997). The role of polyamine catabolism in polyamine analogueinduced programmed cell death. Proc Natl Acad Sci U S A 94, 11557-11562.

Holta, E. (1977). Oxidation of spermidine and spermine in rat liver: purification and properties of polyamine oxidase. Biochemistry 16, 91-100.

Kim, B. G., Sobota, A., Bitonti, A. J., McCann, P. P. \& Byers, T. J. (1987). Polyamine metabolism in Acanthamoeba: polyamine content and synthesis of ornithine, putrescine, and diaminopropane. J Protozool 34, 278-284.

Knodler, L. A., Edwards, M. R. \& Schofield, P. J. (1994). The intracellular amino acid pools of Giardia intestinalis, Trichomonas vaginalis, and Crithidia luciliae. Exp Parasitol 79, 117-125.

Libby, P. R., Henderson, M., Bergeron, R. J. \& Porter, C. W. (1989). Major increases in spermidine/spermine $N^{1}$-acetyltransferase activity by spermine analogues and their relationship to polyamine depletion and growth inhibition in L1210 cells. Cancer Res 49, 6226-6231.

Lindmark, D. G. \& Müller, M. (1974). Biochemical cytology of trichomonad flagellates. II. Subcellular distributions of oxidoreductases and hydrolases in Monocercomonas sp. J Protozool 21, 374-378.

Linstead, D. \& Cranshaw, M. A. (1983). The pathway of arginine catabolism in the parasitic flagellate Trichomonas vaginalis. Mol Biochem Parasitol 8, 241-252.

Marton, L. J. \& Pegg, A. E. (1995). Polyamines as targets for therapeutic intervention. Annu Rev Pharmacol Toxicol 35, 55-91.

Mondovi, B., Avigliano, L. \& Morpurgo, L. (1988). In vitro specificity of $\mathrm{Cu}$-amine oxidase inhibitors. Pharmacol Res Commun 20, 39-43.

Müller, M. (1989). Biochemistry of Trichomonas vaginalis. In Trichomonads Parasitic in Humans, pp. 53-83. Edited by B. M. Honigberg. New York: Springer.

Pavlov, V., Nikolov, I., Damjanov, D. \& Dimitrov, O. (1991). Distribution of polyamine oxidase activity in rat tissues and subcellular fractions. Experientia 47, 1209-1211.
Pegg, A. E., Wechter, R., Pakala, R. \& Bergeron, R. J. (1989). Effect of $N^{1}, N^{2}$ - bis(ethyl)spermine and related compounds on growth and polyamine acetylation, content, and excretion in human colon tumour cells. J Biol Chem 264, 11744-11749.

Porter, C. W., Ganis, B., Libby, P. R. \& Bergeron, R. J. (1991). Correlations between polyamine analog-induced increases in spermidine/spermine $N^{1}$-acetyltransferase activity, polyamine pool depletion, and growth inhibition in human melanoma cells lines. Cancer Res 51, 3715-3720.

Reis, I. A., Martinez, M. P., Yarlett, N., Johnson, P. J., Silva-Filho, F. C. \& Vannier-Santos, M. A. (1999). Inhibition of polyamine synthesis arrests trichomonad growth and induces destruction of hydrogenosomes. Antimicrob Agents Chemother 43, 1919-1923.

Santoro, G. F., Yarlett, N. \& Vannier-Santos, M. A. (1999). Effects of polyamine analogues on Trichomonas vaginalis. Acta Microscop 8, 645 .

Segal, I. H. (1976). Biochemical Calculations. New York: Wiley. Seiler, N. (1987). Function of polyamine acetylation. Can J Physiol Pharmacol 65, 2024-2035.

Tabor, C. W. \& Tabor, H. (1984). Polyamines. Annu Rev Biochem 53, 749-790.

Wallace, H. M. (1987). Polyamine catabolism in mammalian cells: excretion and acetylation. Med Sci Res 15, 1437-1440.

Woster, P. M. (1993). Spermidine/spermine $N^{1}$-acetyltransferase (SSAT) - an emerging target for the design of anti-tumour agents. Curr Opin Invest Drugs 2, 1291-1299.

Yarlett, N. (1988). Polyamine biosynthesis and inhibition in Trichomonas vaginalis. Parasitol Today 4, 357-360.

Yarlett, N. \& Bacchi, C. J. (1988). Effect of DL- $\alpha$-difluoromethylornithine on polyamine synthesis and interconversion in Trichomonas vaginalis grown in a semi-defined medium. Mol Biochem Parasitol 31, 1-10.

Yarlett, N. \& Bacchi, C. J. (1994). Parasite polyamine metabolism: targets for chemotherapy. Biochem Soc Trans 22, 875-880.

Yarlett, N., Goldberg, B., Moharrami, M. A. \& Bacchi, C. J. (1993). Trichomonas vaginalis: characterization of ornithine decarboxylase. Biochem J 293, 487-493.

Yarlett, N., Lindmark, D. G., Goldberg, B., Moharrami, M. A. \& Bacchi, C. J. (1994). Subcellular localization of the enzymes of the arginine dihydrolase pathway in Trichomonas vaginalis and Tritrichomonas foetus. J Euk Microbiol 41, 554-559.

Yarlett, N., Martinez, M. P., Moharrami, M. A. \& Tachezy, J. (1996). The contribution of arginine dihydrolase pathway to energy metabolism by Trichomonas vaginalis. Mol Biochem Parasitol 78, 117-125.

Received 21 February 2000; revised 20 June 2000; accepted 18 July 2000. 